\title{
The Foreclosed Collaterals As A Resolution For Bad Credit In Indonesia Banking System
}

\section{Sriwati Sutomo*)}

${ }^{*}$ Faculty of Law, Universitas Surabaya (UBAYA), Indonesia, E-mail: sriwati@ubaya.ac.id

\begin{tabular}{l}
\hline Article \\
\hline Keywords: \\
Banks; Collaterals; \\
Foreclosed; Mortgage; \\
Rights..
\end{tabular}

\section{Article History}

Received: 2021-11-16;

Reviewed: 2021-11-25;

Accepted: 2021-11-27;

Published: 2021-11-28.

DOI:

http://dx.doi.org/10.30

659/jdh.v4i4.18061

Abstract.

This research aim to understand the condition when a customer

is no longer able to pay or repay a loan is called bad credit. This condition can actually cause many problems, ranging from difficulties in obtaining credit approvals to blacklisting by the bank. Collaterals are one of the requirements from the Bank when giving credit loans so that those collaterals can guarantee the credit's acquittal should the debtor be breached. If there is a case of bad debts, banks have the option to solve the credit loan through the process of Foreclosed Collaterals. This journal is written on a legal and juridical-normative research, emphasizing the usage of written documents as the main sources of law. The collateral purchases are written in Article 12A Number 10 of 1998 of the Constitution on how banks may purchase the collaterals with or without auctions to solve bad credits even faster. Considering that Article 20 of the Constitution on Mortgage Rights has already written ways on collateral executions, therefore the warrant payment will follow the option of Foreclosed Collaterals. Reporting from the official website of Bank Indonesia (BI), to minimize the risk of increasing bad loans, BI issued PBI (Bank Indonesia Regulation) No. 14/2/PBI/2012 concerning APMK (Card-Based Payment Instruments). The regulation was made to reduce the risk of negative impacts from using credit cards as debt instruments to the extent that they reach excessive limits. Using statute and conceptual approaches, it is inferred that Foreclosed Collateral purchase procedures can be done in 3 (three) different ways, followed through the Settlement Efforts, where the ownership of the collaterals must be switched to another in 1 (one) year time.

(C)2021; This is an Open Access Research distributed under the term of the Creative Commons Attribution License (https://Creativecommons.org/licences/by/4.0), which permits unrestricted use, distribution, and reproduction in any medium, provided the original works is properly cited

\section{Introduction}

Indonesian Banks are strategic tools to improve the country's development, economic growth, and national stability to improve the quality of people's lives. This is because banks are categorized as intermediary institutions. This is regulated within Article 1 Number 2 of Act No. 10 of 1998 of Act No. 7 of 1992's Amendment regarding Banks (later referred to as Act No. 10 of 1998) which defined banks as "business entities that collect funds from the community in the form of savings and distribute them to the community in the form of credit and or other forms in order to improve the living standards of many people." It is emphasized even further within Article 3 Number 7 of Constitution of 1992 on Banks (later known as Act No. 7 of 1992), "The main function of Indonesian banking is to collect and distribute public funds." Banks function both by gathering money from the depositors (surplus) and transferring the money to the debtors (deficit). Banks as intermediary institutions can operate on various business activities, as regulated in Article 6 Number 10 of 1998, one of which is credit loans. 
The word "credit" is a commonly known term by the people in money lending and loaning practices. The word is derived from Romans' language translated as "credere" meaning "believe" or "credo" or "creditum" which means "I believe". ${ }^{1}$ Article 1 Number 11 of the Constitution on Banking defined credits as:

Credit is the provision of money or equivalent claims, based on an agreement or loan agreement between a bank and another party that requires the borrower to repay the debt after a certain period of time with the amount of interest, compensation or profit sharing.

Relationships between Banks and debtors are based on mutual trust, so the funds provided are cashed out due to the bank's belief in the customers. Therefore, the relation between the two parties is an interpersonal relationship ${ }^{2}$. This relation is later brought upon a written contract, commonly known as credit agreement. According to Remy Sjahdeini, credit agreements are: ${ }^{3}$

Agreements between banks as creditors and customers as debtors regarding money loans or similar debts which oblige the debtors to pay off their debts after a certain time has passed with the amount of interest, compensation, or expenses sharing.

To this day, there have been no specific regulations regarding the forms and contents of the Credit Agreement, thus the regulations are often left to the mutual agreements of both parties involved. Credit Agreements are commonly made by Banks following the corresponding funding facilities provided should the loaners' needs match with the agreements, the customers will be given full access to the agreement. This agreement will be the guardrails for the banks and the customers so that as long as the agreement is valid, both can follow the articles contained within the agreement, so there will be no breaches towards the contract.

The bank's main function as money distributor and gatherer solely relies on trust on the relationships of the bank and the people as customers. Without it, the people would not consider making a saving on the bank, consequently banks will not be able to distribute the fund back to the people. The demand to maintain the trust between banks and the customers in its daily operations is in accordance with Article 6 Number 7 of 1992 of the Constitution that it is a must to always watch over and prioritize caution. Other than that, caution is also necessary to secure the safety of the Banks themselves because they keep and manage the people's finances, therefore a threat of carelessness when conducting business can affect the funds' security entrusted by the customers. Thomas Hellman, Kevin Murdock, and Joseph Sitghlizt mentioned that caution or prudential principle in bank operation is necessary, because:

Prudential regulation is meant to protect the banking system from these problems. Traditionally, it consisted of a mixture of monitoring individual transactions (ensuring, for instance, that adequate collateral put up), regulations concerning selfdealing, capital requirements and entry restrictions. In some countries, restrictions were placed on lending in particular areas-many East Asian Countries, for example, used to have restrictions on real estate lending. Finally, many countries imposed

\footnotetext{
1Johannes Ibrahim. (2004). Cross Default and Cross Collateral Sebagai Upaya Penyelesaian Kredit Bermasalah. Bandung: Refika Aditama. p.22.

2lbid., p.2.

${ }^{3}$ Salim H.S. (2010). Perkembangan Teori Dalam Ilmu Hukum. Jakarta: Rajawali Pers. p.78.
} 
interest rate restrictions. Concerns about bank runs also led many countries to provide deposit insurance and to establish central bank to serve as lenders of last resort ${ }^{4}$.

According to Ferry N. Idroes, regulations within a bank's systems are intended to protect it from risks and to secure both the customers and the economy from the failed process and procedure which in turn may affect the financial systems. This is because each of the bank's activities has its own risks, therefore the system always follows risk management. Banks must proceed with prudence on its operations to avoid any risks ${ }^{5}$. One of the most commonly used businesses in banks is loaning credits, therefore, there is a potential threat called credit risk. To lessen and even avoid the possibility, precautions are done before, during, even after the credits are given. One of the steps during a credit loan is doing a thorough credit analysis, so that the bank can determine the capacity and needs of the customers to be able to return the loaned money. The analysis is done through 5 (five) C's of Credits factors, which are: character, capacity, capital, collateral, and condition of economy. Among the five, one important aspect that Bank may demand during credit loans are warrants or collaterals.

Collaterals or warrants can be in the form of movable and immovable properties which are commonly warranted to the bank. If debtors are not able to pay back their loans, banks have the right to sell their warrants to pay back the loan using preference rights which are the rights to have the credit payment paid faster than other creditors (concurrent creditors). The collaterals will lessen the loss risk which may emerge one day so it does not create unhealthy economic conditions when the debtors are not able to return the loaned money. As the money loaned by the bank is kept by the customers, the bank will only distribute the money and get profits based on the interests. Thus, collaterals are essential in credit loans. Common forms of warrants are land and or/ buildings as in movable and immovable properties, for example raw and finished materials from the debtors. Should the warranted objects be immobile properties like lands or buildings, then the warrant will be charged unto Mortgage Loan institutions, whereas the movable properties will be governed by the Fiduciary Guarantee.

Mortgage Rights within Act No. 4 of 1996 concerning Mortgage on Lands and Objects Related to Land (later referred to as Act No. 4 of 1996) is defined as "Security rights imposed on land rights as referred to in Act No. 5 of 1960 concerning Basic Regulations on Agrarian Principles, including or not including other objects is a unit with the land, for the settlement of certain debts, which gives priority to certain creditors over other creditors." If the debtors breach the agreement and are unable to repay back the loans as agreed in the credit agreement, then actions can be done on mortgaged properties, such as the lands/ or buildings. Written in Number 4 of 1996 of the Constitution, there are three ways on how to resolve the bad credit via mortgaged rights:

- Article 6 Number 4 of 1996 of the Constitution via public auctions (parate executie);

- Article 14 Number 4 of 1996 of the Constitution via executive titles (fiat executie);

- Article 20 Section (2) Number 4 of 1996 of the Constitution via private deeds

\footnotetext{
${ }^{4}$ Trisadini P. Usanti and Abd. Shomad. (2017). Hukum Perbankan. Jakarta: Kencana. p.119.

${ }_{5}^{5}$ Ferry N. Idroes. (2008). Manajemen Risiko Perbankan: Pemahaman Pendekatan 3 Pilar Kesepakatan Basel II Terkait Aplikasi Regulasi dan Pelaksanaannya di Indonesia. Jakarta: Rajawali Press. p.30.
} 
following the agreement between the receiver and owner of the Mortgage Rights.

Article $12 \mathrm{~A}$ of the Constitutions on Banking provides other available ways for banks to deal with breached debtors who are unable to return the borrowed money through temporary collaterals. This process is later referred to as Foreclosed Collaterals. This process involves buying half or all of the warrants if the debtors are not able to fulfill his/her duty. Explained within Article 12A section (1) Number 10 of 1998 of the Constitution that the purchase is temporary and has to be sold to other parties as fast as possible. Rules regarding warrants takeover are also included in Section 1 Number 25 of Financial Services Authority Constitutions (POJK) Number 16/POJK/ 03/2014 about Islamic Public Bank Assets Quality Assessment and Islamic Business Units: "Half or entire assets obtained by banks through purchase in or out of auctions based on purchase in or out of auctions or through the right bestowed by the owners to sell the collaterals where the debtors may not fulfill the rights to the bank."

Foreclosed Collaterals process depends on each bank's authorities which is also done through agreements between banks and debtors. There are not many rules and procedures of Foreclosed Collaterals so currently it follows the guidelines of Constitutions of Banks and Financial Service Authority (OJK) and Financial Minister Rules (PMK). Thus, the statements of the problem for this journal will be the validity of bad credit resolution in banks through Foreclosed Collaterals.

\section{Research Methods}

This journal is written on a legal and juridical-normative research, emphasizing the usage of written documents as the main sources of law, for example: The Constitutions, court verdicts, law theories, and law bachelors' opinions. According to Peter Mahmud Marzuki: "Law studies are done to resolve the current law issues" ${ }^{6}$. Approaches used are statute and conceptual approaches. Statute approach is an approach done by examining all constitutions and regulations related to the issue ${ }^{7}$. This journal will cover the Foreclosed Collaterals methods as written in the Banking Constitutions and Mortgage Rights Constitutions. The second angle is through the conceptual approach where studies are done through studying jurisprudence doctrines ${ }^{8}$.

The 2 (two) law materials used for this research are primary and secondary law materials. Primary materials used are the Indonesian law's constitutions:

- Act No. 5 of 1960 on Agrarians Basic Regulations;

- Act No. 4 of 1996 regarding Mortgage Rights;

- Act No. 7 of 1992 on Banking;

- Act No. 10 of 1998 on Act No. 7 of 1992 Amendment on Banking;

- Ministry of Finance Regulation Number 27/PMK.06/2016 on Auction Instructions;

- Financial Service Authority's Regulation Number 40/POJK.03/2019 on Public Banks Assets' Quality Assessment.

Secondary law materials are the published texts containing the primary materials, in the forms of literatures and related journals.

\footnotetext{
${ }^{6}$ Peter Mahmud Marzuki. (2017). Penelitian Hukum. Jakarta: Kencana. p.60.

${ }^{7}$ Ibid., p.137.

${ }^{8}$ Ibid., p.178.
} 


\section{Results and Discussion}

Banks run business and gain profits by providing financial services to the people. Despite this, banks have various risks. Article 4 of Financial Services Authority (OJK) 18/2016 listed 8 (eight) risks banks commonly face, which are:

- Credit Risks;

- Market Risks;

- Liquidity Risks;

- Operational Risks;

- Law Risks;

- Reputation Risks;

- Strategic Risks;

- Compliance Risks.

Commonly used business operations in banks are credit loans, therefore credit loans are one of the biggest sources of income for banks. However, on the other hand, credits can also be the biggest risk, the credit risk. This kind of risk rises due to the inability of a party to fulfill their duties to the bank, such as debtors failing to pay their debts, credit concentration risks, counterparty credit risk, and settlement risk. If debtors do not manage to pay their debts on due time will create bad credits (non-performing loan or NPL). ${ }^{9}$

Article 12 of Financial Services Authority (OJK) Number 40/POJK 03/2019 about Banks' Assets' General Quality Assessment (later known as POJK Number 40/POJK.03/2019) specified regarding credit qualities into Pass, Special Mention, Substandard, Doubtful, or Loss. The determining factor is done through an analysis towards business prospects, debtor's performance, and the debtor's capacity as regulated in Article 10 juncto Article 11 POJK 40/2019.

The classification of the credit qualities that are viewed from the punctuality of the principal and interest payments are as follows:

- Current Credits, payment done on time;

- Credits on Special Mention, there is a principal payment and interest arrears up to 90 days;

- Substandard Credits, there is a principal payment and interest arrears within 90 up to 120 days;

- Doubtful Credits, there is a principal payment and interest arrears within 120 up to 180 days;

- Loss Credits, there is a principal payment and interest arrears past 180 days.

From these classifications, what is included as bad debts are debts which have arrears past 90 days or categorized as Substandard, Doubtful, and Loss ${ }^{10}$. If credits are categorized as bad debts and debtors are valued as breached. ${ }^{11}$ Banks have the obligations to resolve excessive bad credits because they can affect Banks' wellbeing as

\footnotetext{
${ }^{9}$ Sutarno. (2003). Aspek-Aspek Hukum Perkreditan pada Bank. Bandung: Alfabeta. p. 95-96.

${ }^{10}$ Alfis Setyawan. (2016). Tinjauan Yuridis Penggunaan Surat Kuasa Jual Terhadap Penjualan Objek Hak Tanggungan Dalam Penyelesaian Kredit Macet. Jurnal Cahaya Keadilan. 4.1, 1-21. p.16.

${ }^{11}$ Trisadini Prasastinah Usanti dan Nurwahjuni. (2014). Model Penyelesaian Kredit Bermasalah. Surabaya: Revka Petra Media. p.38.
} 
written in Article 3 Section (2) letter d POJK 15/2017 on how banks will be put under intense surveillance if they have potential risks that endanger their business, one of them is bad debts ratio (Non-Performing Loan/NPL net) more than $5 \%$ (five percent) from the total amount of credit. ${ }^{12}$ To solve bad credits, banks often take actions on collaterals warranted on the previous agreement. The process of credit collateral execution can be difficult, one of the problems which may appear is the property's price falling during auction or there are no buyers available. ${ }^{13}$

With this in mind, the Constitution on Banking allows banks to purchase some or all of the collaterals in hopes that by doing so, bad credits are resolved faster and achieve the best result. Article 12A Section (1) Number 10 of 1998 of the Constitution mentions that:

Public Banks may buy half or all of the collaterals, in or outside of auctions on voluntary submissions of the collaterals' owner or the rights to sell the collaterals bestowed by the owner where the debtors fail to fulfill the responsibility to the banks, following the terms of service where the collaterals must proceed immediately.

Act No. 10 of 1998 does not use the term Foreclosed Collaterals. The Article $12 \mathrm{~A}$ Number 10 of 1998 is then defined more specifically within POJK Number 40/ POJK 03/2019. Article 1 Number 15 POJK Number 40/ POJK. 03/2019 a new term rises called Foreclosed Collaterals and its definition: "Assets obtained from banks through or not through auctions from voluntary submission from the collaterals' owner or the right to sell the collaterals outside of auctions by the collaterals' owner should the debtors do not manage to fulfill responsibility to the bank." It can be concluded from this statement that Foreclosed Collaterals are assets acquired by banks, from or not from auctions, because the collaterals' owner and debtor do not manage to pay back the bank. The collateral takeover in the form of land and buildings has to be done should the credit be included as bad credit. Foreclosed Collaterals are done in several steps and involve certain parties, particularly banks and debtors and/or the rightful owner of the lands and buildings warranted by the Mortgage Rights ${ }^{14}$.

The purposes of Foreclosed Collaterals are: ${ }^{15}$

- Reduce the amount of bad credits in banks;

- Speed up and expedite the process of bad debts resolution, this is possible because of the decisions between banks and debtors;

- Anticipate short term effects of the increasing cases of bad debts.

Article 12A Section (2) of the Constitution on Banking mentions collaterals that can be bought by banks are those which are included in bad debts for a certain period of time. Collaterals that have been purchased have to be cashed out not later than one-

\footnotetext{
12 Denita Cahyanti Wahono. (2021). Bea Perolehan Hak Atas Tanah dan Bangunan Dalam Pembelian Agunan Sementara. Surabaya: Universitas Airlangga. p.38.

13 Lady Davina Windsor Enoch. (2019). Penyelesaian Kredit Macet Melalui Pembelian dan Penjualan Agunan oleh Pihak Bank Menurut Undang-Undang No. 10 Tahun 1998 Tentang Perbankan. Lex Privatum. 7.1, 75-82. p.77.

${ }^{14}$ Nur Muhammad Dilapanga. (2021). Agunan Yang Diambil Alih: Sebuah Mekanisme Dalam Penyelesaian Kredit Macet. Jurnal Ilmu Sosial dan Pendidikan, 5.2, 156-163 .p.158.

15 Nalia Safitri. (2013). Peranan Notaris dalam Pelaksanaan Pengambilalihan Aset Debitor (AYDA) Sebagai Alternatif Penyelesaian Kredit Macet Pada Bank. Jakarta: Universitas Indonesia). p.84.
} 
year period, where in a year banks may suspend responsibilities regarding collateral rights takeover. Foreclosed Collaterals must be conducted in marketing and selling because the taken over collateral objects are left to the bank due to the fact that land and/or buildings are immovable assets. In Article 1 number 4 of the Constitution on Banking, Foreclosed Collaterals are among the non-productive assets of banks so prolonged ownership of the collaterals can dilute the bank's well-being. The prolonged ownership also affects their qualities as written in Article 37 POJK 40/2019 which categorizes Foreclosed Collaterals unto 4 different kinds:

- Current, collaterals owned for 1 (one) year;

- Substandard, collaterals owned for 1 (one) up to 3 (three) years;

- Doubtful, collaterals owned for 3 (three) up to 5 (five) years;

- Loss, collaterals owned for more than 5 (five) years.

There are several hindrances that banks face to solve bad credits through Foreclosed Collaterals, such as: ${ }^{16}$

- Possible expenses to conduct collateral auctions between banks and debtors such as taxes, finance certificates costs, and title transfer tax;

- Collaterals becoming bank assets which require decisions from General Meeting of Shareholders to do a takeover on those collaterals;

- Regulations to switch the ownership of the collateral within 1 (one) year is not an easy thing to do because of the difficulties in selling land and/or building properties.

Collaterals purchase by banks are done through or not through auctions. Purchase through auctions is written in Article 78 Section (1) PMK 27/2016 that regulated banks as creditors may buy the collaterals through auctions by delivering a statement letter in the form of Notary Deeds containing the statement where the purchase is done for the sake of other people which later be decided within 1 (one) year starting from the date the auction is done. If banks do not manage to find a potential buyer within 1 (one) year then the warrants are automatically be left in charge of the banks. Purchases outside of auctions can be made by voluntary submission from the warranted objects' owner or from a right to sell the collaterals from the owner. Foreclosed Collaterals done outside of auctions can be done by creating the right to sell from debtors to the bank in a time period as written in Article $12 \mathrm{~A}$ of the Constitution on Banking, which is 1 (one) year, where if Banks cannot sell the collaterals then banks are decided as its buyer. Other than that, debtors may create an asset submission agreement to resolve credits. ${ }^{17}$

Credit resolution through Foreclosed Collaterals is done in order to haste the process of collaterals, so it does not put banks at a disadvantage with prolonged process. However, there is a limitation on this process as banks are financial institutions whose business operations do not run on buying or selling in search of profits. Therefore, Foreclosed Collaterals is a legal procedure and can be an option on bad credit resolution to make the process easier, as long as the collaterals are not owned by the banks.

\section{Conclusion}

Foreclosed Collaterals is a legal option that banks can choose to resolve bad credit

\footnotetext{
${ }^{16}$ Sutarno, Op. Cit., p.272.

${ }^{17}$ Natalia Safitri, Op. Cit., p.87.
} 
as regulated within the Article 12A Number 10 of 1998 of the Constitution. Following this method, it is expected that the process of credit settlement goes faster and easier in order to prevent and avoid breaches within banks due to the bad credits.

\section{References}

\section{Journals:}

[1] Alfis Setyawan. (2016). Tinjauan Yuridis Penggunaan Surat Kuasa Jual Terhadap Penjualan Objek Hak Tanggungan Dalam Penyelesaian Kredit Macet. Jurnal Cahaya Keadilan, 4.1, 1-21.

[2] Lady Davina Windsor Enoch. (2019). Penyelesaian Kredit Macet Melalui Pembelian dan Penjualan Agunan oleh Pihak Bank Menurut Undang-Undang No. 10 Tahun 1998 Tentang Perbankan. Lex Privatum, 7.1, 75-82.

[3] Nur Muhammad Dilapanga. (2021). Agunan Yang Diambil Alih: Sebuah Mekanisme Dalam Penyelesaian Kredit Macet. Jurnal Ilmu Sosial dan Pendidikan, 5.2, 156-163.

\section{Books:}

[1] Johannes Ibrahim. (2004). Cross Default and Cross Collateral Sebagai Upaya Penyelesaian Kredit Bermasalah. Bandung. Refika Aditama.

[2] Salim H.S. (2010). Perkembangan Teori Dalam Ilmu Hukum. Jakarta. Rajawali Pers.

[3] Trisadini P. Usanti dan Abd. Shomad. (2017). Hukum Perbankan. Jakarta.Kencana.

[4] Ferry N. Idroes. (2008). Manajemen Risiko Perbankan: Pemahaman Pendekatan 3 Pilar Kesepakatan Basel II Terkait Aplikasi Regulasi dan Pelaksanaannya di Indonesia. Jakarta: Rajawali Press.

[5] Peter Mahmud Marzuki. (2017). Penelitian Hukum. Jakarta. Kencana.

[6] Sutarno. (2003). Aspek-Aspek Hukum Perkreditan pada Bank. Bandung. Alfabeta.

[7] Trisadini Prasastinah Usanti dan Nurwahjuni. (2014). Model Penyelesaian Kredit Bermasalah. Surabaya: Revka Petra Media.

\section{Thesis:}

[1] Denita Cahyanti Wahono. (2021). Bea Perolehan Hak Atas Tanah dan Bangunan Dalam Pembelian Agunan Sementara. Surabaya: Universitas Airlangga,).

[2] Nalia Safitri. (2013). Peranan Notaris dalam Pelaksanaan Pengambilalihan Aset Debitor (AYDA) Sebagai Alternatif Penyelesaian Kredit Macet Pada Bank. Jakarta: Universitas Indonesia. 